\title{
Training in robotic surgery: initial experience using the Brazilian College of Surgeons model
}

\section{Treinamento em cirurgia robótica: experiência inicial pelo modelo do Colégio Brasileiro de Cirurgiões}

Fernando de Barros, tCBC-Rj1,2 [i]; Veronica Bernardino Felicio²; Ana Caroline lima Tabet²; Ana Carolina Capuano Cerbone².

\author{
A B S T R A C T
}

\begin{abstract}
Objective: to present the initial experience of the first tier of surgeons trained in the new model of robotic surgery training proposed by the CBC. Methods: we retrospectively collected data and information on training with the Da Vinci SI robotic system. The variables analyzed were, in the pre-clinical phase, time of completion of each step by surgeon and number of hours in the simulator, and in the clinical phase, operations carried out by the training group, number of surgeons who performed nine procedures in ninety days (" 9 in $90 "$ ), time of docking, time of console, and results surgical. Results: we interviewed 39 surgeons before training started; 20 ( $51.3 \%$ ) reached the clinical phase. The average age of surgeons was 47.9 years (38-62). The average time between the first interview and the delivery of the online certificate was 64 days (15-133). The surgeons have made an average of $51 \mathrm{~h}$ and 36 minutes of robot simulation (40-83 hours). The total number of cases in which the training surgeons participated as first assistant was 418 , with an average of 20.9 per surgeon. The time of pre-clinical training had an average of 116 days (48-205). Conclusion: the new model proposed had good acceptance by all surgeons trained and proved safe in the initial sample.
\end{abstract}

Keywords: Robotic Telesurgery, Training, Robotic Surgical Procedure.

\section{INTRODUCTION}

$\mathrm{R}$ obotic surgery has been initially accomplished with platforms used for neurosurgical biopsies, called Programmable Universal Machine for Assembly (PUMA) $200^{1}$. Since then, many platforms evolved and, in 1998, Computer Motion introduced the Zeus system, in which the surgeon controls arms and instruments². However, the greater impact on the evolution of robotic surgery was when Intuitive Surgical developed the Da Vinci platform, in 1998.

Since then, the robotic surgery has been growing exponentially, as well as the number of surgeons adopting the method. This demand eventually created the need for training of surgeons to operate the machine safely ${ }^{3}$. However, the certification process had been being carried out worldwide by the company which owns the Da Vinci platform4.
In 2020, in an unprecedented action, the Commission of Minimally Invasive and Robotic Surgery of the Brazilian College of Surgeons (CBC) lunched an initiative for the establishment of a certification, based on objectives and validated criteria, for the conduction of robotic procedures, based on a document of the Brazilian Medical Association ${ }^{5}$. Essentially, training becomes a responsibility of each hospital, divided into four steps: 1) Introduction to robotic system; 2) Theoretical-practical training on the robotic platform; 3) Pre-clinical training; 4) Clinical training under mentoring.

\section{OBJECTIVE}

We present the initial experience of our program during the first year of training, of the first surgeons tier, with this new model of training in robotic surgery proposed by the CBC.

1 - Universidade Federal Fluminense, Departamento de Cirurgia Geral e Especializada - Niterói - RJ - Brasil 2 - Hospital São Lucas, Departamento de Cirurgia Geral - Rio de Janeiro - RJ - Brasil 


\section{METHODS}

The study was submitted to the Ethics in Research Committee (CAEE 67889617.3.0000.5533) and approved by Opinion 2,200,788 of CEP, PróCardíaco-ESHO Empresa de Serviços Hospitalares. The period of recruitment (interview) was from January to December 2020 in a continuously flow in the program. Since this work is only descriptive, we use sampling by convenience. We retrospectively collected data in the São Lucas Copacabana hospital system on the initial experience with the new surgeons trained in the model recommended by the $C B C$ on the robotic platform $D a$ Vinci SI. All surgeons trained met the following criteria: professional qualification and specialty (RQE) in any surgical area; minimum experience of five years in the respective specialty; and be duly registered at the hospital specialty service.

Figure 1 summarizes the training flow. After the interview with the coordination of the robotic surgery program, the first step required of the surgeon in the preclinical phase was the conclusion of the online course at the Intuitive site that introduces the robotic system. After the delivery of the certificate, the surgeon was introduced to the simulator (Simbionix -Endocompany ${ }^{\circledR}$ ) along with the robotic assisting nurse, previously trained and qualified in the simulator. Scheduling of the simulator was freely opened, with total autonomy for the surgeon to schedule training sessions. We considered the simulation phase completed when the surgeon reached 40 hours, with at least $80 \%$ proficiency in all simulator exercises, among these, camera navigation, clutching, setup of the fourth arm, delivery of energy, manipulation of the endowrist, suturing, perception of depth, and manual dexterity. There was no training with live tissue or use of animals in the laboratory.

During the simulation phase, the surgeon was encouraged to perform 10 cases as the first assistant for robotic surgeries performed at the hospital. All participated in the robotic surgery theoretical course (from basics to specialty), with minimum eight hours evaluation time. To pass to the next training step, the surgeon needed a $70 \%$ grade in the theoretical course. During this period, we offered a collection of robotic procedures via internet and encouraged the trainees to attend at least five procedures of their specialty.

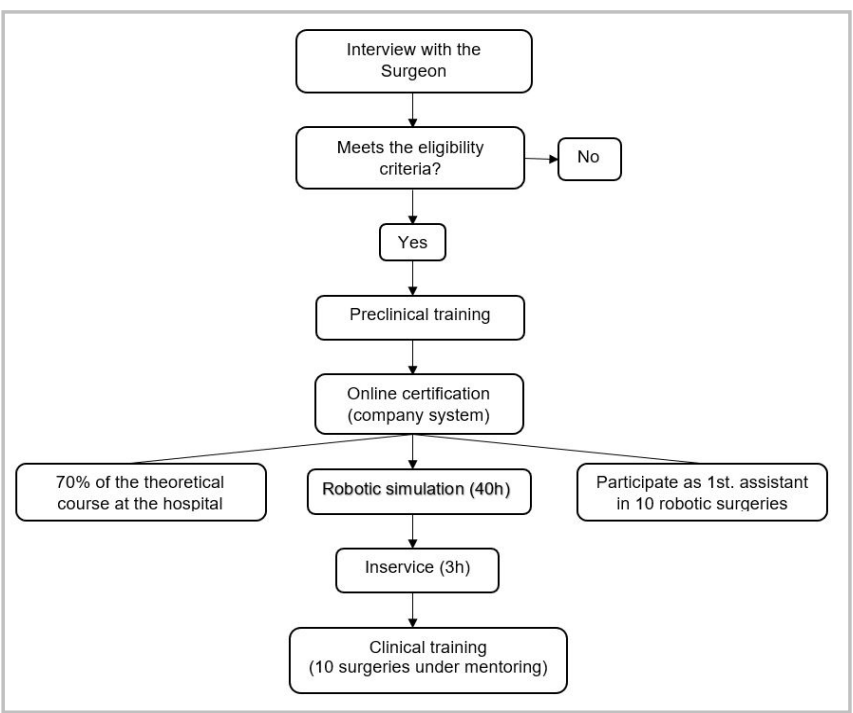

Figure 1. Training algorithm.

For theoretical and practical training in the robotic platform (Inservice), the surgeon ought to complete all the previous steps and have at least two operations scheduled within two weeks. During the Inservice phase, all were trained to master the operating room setup, system setup, robotic drape placement, movement of the patient robotic cart, port placement, docking, solving any issues with the platform, and predetermined exercises: third arm movement, suturing, and camera movement. The Inservice phase lasted three hours for each surgeon.

We expressed continuous variables as average and range, those being time of completion of each of the steps by the surgeon, number of hours needed to complete the proficiency in the simulator, total number of operations carried out by the training group, number of surgeons who performed nine procedures in ninety days ("9 in 90" - goal strategy proposed by Intuitive), time of docking, time of console, surgical results, and number of surgeons with complete mentored clinical training.

\section{RESULTS}

Although the recruitment period was between January the December 2020, all operations were performed in the period from March to December 2020 due to uncontrollable reasons at the time of the study (pandemic 
by SARS COV2). We interviewed 39 surgeons for the start of training, 20 of them (51.3\%) having reached the clinical phase, and among them, five (25\%) have completed it and, as of this writing, operate without the need of a preceptor. The average age among surgeons was 47.9 years (range 38 62) (Table 1). The average time between the first interview and the delivery of the online certificate was 64 days (range 15-133). As for the simulator, the surgeons performed an average of 51 hours and 36 minutes (range
4083 hours) of simulation. The average time to reach $80 \%$ skill proficiency in the exercise was 29 hours and 34 minutes (range 13-35 hours) of simulation. Sixteen (80\%) surgeons reached the required proficiency in less than 40 hours. The total number of cases in which the training surgeons participated was 418 , with an average of 20.9 cases per surgeon. The average time of pre-clinical training was 116 days (range 48-205). Among the 124 operations performed, 13 (10.5\%) took place without a preceptor.

Table 1. Characteristics of surgeries performed.

\begin{tabular}{|c|c|c|c|c|c|c|c|}
\hline \multirow[t]{2}{*}{ Surgery } & \multirow[t]{2}{*}{$\mathrm{n}$} & \multicolumn{3}{|c|}{ Surgery time (min) } & \multicolumn{3}{|c|}{ Docking time (min) } \\
\hline & & Average & Variation & SD & Average & Variation & SD \\
\hline Gastroplasty & 76 & 123.6 & $65-210$ & 30.5 & 7.5 & $3.0-14.2$ & 2.3 \\
\hline Inguinal herniorrhaphy & 13 & 144.0 & $75-230$ & 48.9 & 5.2 & $3.4-6.8$ & 0.9 \\
\hline Partial Colectomy & 10 & 132.5 & $130-135$ & 3.5 & 9.1 & $6.11-11.2$ & 1.8 \\
\hline Hysterectomy & 6 & 153.8 & $68-215$ & 51.9 & 4.9 & $3.2-6.5$ & 1.5 \\
\hline Reflux & 6 & 134.2 & $65-225$ & 58.7 & 8.0 & $6.6-8.7$ & 0.8 \\
\hline Cholecystectomy & 3 & 83.0 & $65-101$ & 25.5 & 5.8 & $5.4-7.2$ & 1.1 \\
\hline Prostatectomy & 3 & 263.3 & $240-305$ & 36.2 & 8.3 & $7.5-9.7$ & 1.2 \\
\hline Duodenopancreatectomy & 2 & 385.5 & $337-380$ & 30.4 & 13.4 & $12.0-14.4$ & 1.6 \\
\hline Pulmonary Lobectomy & 2 & 215.0 & $190-240$ & 35.4 & 17.2 & $16.7-17.7$ & 0.7 \\
\hline Esophagomyotomy & 1 & & & & & & \\
\hline Mediastinal lymphadenectomy & 1 & & & & & & \\
\hline Nephrectomy & 1 & & & & & & \\
\hline
\end{tabular}

SD - Standard Deviation.

Table 2 brings the records of the number and the characteristics of each surgical procedure. The age of the patients operated was of $43.5 \pm 13.3$ years (range 21-88). The most commonly conducted procedure was gastroplasty, with 76 cases (61.3\%).

There was no unforeseen event or accident with the robotic platform. There was only one death, a patient who was subjected to pancreatoduodenectomy and had major bleeding on the 16th postoperative day. The average time of hospitalization was 2.02 days (range 1-21). At the time of the study conclusion, among the
10 surgeons who had more than 90 days since the first case, six (60\%) reached the proposed target of nine procedures in 90 days.

\section{DISCUSSION}

Few protocols for training in robotic surgery were validated by means of work reviewed by peers. In addition, there is a lack of information on the characteristics of surgeons and training in robotic surgery that impact the surgeon's performance on the console ${ }^{6}$. 
As far as we know, in March 2020, our group held the first operations with the first robotic surgeons trained with this new model designed by the CBC. The idea of this work was to report the first results of the first year, to make a critical analysis, and to convey the impression of the initial clinical practice.

Table 2. Stages of the Pre-clinical and Clinical phases.

\begin{tabular}{|c|c|c|c|c|c|c|c|c|}
\hline Surgeon & $\begin{array}{c}\text { Age } \\
\text { (years) }\end{array}$ & $\begin{array}{c}\text { Online } \\
\text { Certificate } \\
\text { Delivery } \\
\text { Time (Days) }\end{array}$ & $\begin{array}{l}\text { Simulation } \\
\text { time to } \\
\text { achieve 40h } \\
\text { (Days) }\end{array}$ & $\begin{array}{l}\text { Surgeries } \\
\text { as First } \\
\text { Assistant }\end{array}$ & $\begin{array}{l}\text { Preclinical } \\
\text { Training } \\
\text { Time }\end{array}$ & $\begin{array}{l}\text { Number } \\
\text { of } \\
\text { surgeries }\end{array}$ & $\begin{array}{l}\text { Under } \\
\text { Mentoring }\end{array}$ & $\begin{array}{l}\text { Without } \\
\text { Mentoring }\end{array}$ \\
\hline 1 & 54 & 95 & 65 & 10 & 124 & 18 & 10 & 8 \\
\hline 2 & 56 & 105 & 14 & 16 & 158 & 12 & 10 & 2 \\
\hline 3 & 38 & 42 & 56 & 21 & 118 & 11 & 10 & 1 \\
\hline 4 & 41 & 41 & 52 & 160 & 117 & 11 & 10 & 1 \\
\hline 5 & 62 & 15 & 91 & 10 & 205 & 11 & 10 & 1 \\
\hline 6 & 39 & 46 & 27 & 10 & 56 & 9 & 9 & 0 \\
\hline 7 & 46 & 65 & 17 & 31 & 148 & 9 & 9 & 0 \\
\hline 8 & 47 & 73 & 60 & 10 & 190 & 8 & 8 & 0 \\
\hline 9 & 41 & 63 & 63 & 10 & 105 & 6 & 6 & 0 \\
\hline 10 & 39 & 62 & 18 & 18 & 100 & 5 & 5 & 0 \\
\hline 11 & 40 & 44 & 47 & 10 & 99 & 4 & 4 & 0 \\
\hline 12 & 62 & 133 & 36 & 10 & 148 & 4 & 4 & 0 \\
\hline 13 & 54 & 28 & 52 & 19 & 182 & 3 & 3 & 0 \\
\hline 14 & 52 & 81 & 20 & 10 & 54 & 3 & 3 & 0 \\
\hline 15 & 53 & 32 & 26 & 12 & 54 & 3 & 3 & 0 \\
\hline 16 & 48 & 93 & 33 & 10 & 48 & 2 & 2 & 0 \\
\hline 17 & 56 & 117 & 91 & 10 & 154 & 2 & 2 & 0 \\
\hline 18 & 42 & 81 & 80 & 10 & 121 & 1 & 1 & 0 \\
\hline 19 & 38 & 36 & 51 & 10 & 60 & 1 & 1 & 0 \\
\hline 20 & 51 & 37 & 55 & 21 & 71 & 1 & 1 & 0 \\
\hline TOTAL & & & & 418 & & 124 & 111 & 13 \\
\hline
\end{tabular}

There is no doubt about the value of the robotic platform for the evolution of surgery. However, surgeons there are not qualified, are poorly trained, or even are poorly oriented, can put their patients at risk The regulated training offering is fundamental, as well as naming the ones technically responsible the robotic procedure (surgeon, preceptor, and the institution, represented by its technical director). The new rules, with oversight of assignments, responsibility, and training by the institution, with guidance and regulation of medical societies, seem to have good acceptance among the surgeons of the country, as already published ${ }^{5,8}$.

The experience gained in recent years in established programs can no doubt influence the outcome of this new training model. The first point to be discussed is the completion of the pre-clinical phase by little more than half of the initially enrolled surgeons. We believe that the pandemic has in some way interfered with the adherence of some surgeons, who preferred not to go to the hospital in the study period. Besides 
that, despite the interest initially shown by many, these could not manage to adapt to the day to day training, which in fact influences the surgeon's performance and can be deterring during the training programs ${ }^{9}$.

The time between the interview with the coordinator and the delivery of the online certificate was on average of 64 days. This is long, reflected in the great difficulty of the surgeons with the current assessment offered on the company's site. This assessment is passing by constant changes and, in our opinion, need to be revised, since many issues addressed are of engineering technical order and non surgical.

As long-established, simulation and repetition in surgery are critical ${ }^{10}$. The training in robotic surgery simulation is without doubt a great technical education tool for new technologies in surgery ${ }^{11}$. The time of simulation proposed to surgeon was 40 hours, with a minimum of $80 \%$ proficiency. The great majority (80\%) achieved proficiency with less than $40 \mathrm{~h}$, what we deemed sufficient for the next training steps - Inservice and the clinical phases. We believe that training in animals can be useful, however not necessarily mandatory, in accordance with the new resolution ${ }^{5}$. None of the training surgeons studied trained in animals.

It is noteworthy the number of robotic procedures with the involvement of surgeons, 418 for 20 surgeons, averaging 20.9 operations per surgeon. In fact, three of the trained surgeons already worked in teams with large volumes of robotic surgery, what caused the boosted average. Together, the three participants operated on 212 cases (50.7\%). Clearly, these surgeons got easily through the clinical training phase (port placement and docking). Nonetheless, in general 10 cases were enough for every surgeon to feel comfortable with the Da Vinci Si platform and thus pass to the clinical training phase. As Zhao et al. reported, the progression of the first assistant in the field to the console is fundamental and necessary, as it gives the trainee great confidence in handling the platform $^{12}$. This phase of training (pre-clinical) had an average of 116 days and the longest part of this time was for the online certification, as mentioned.

Gastroplasty was the most common operation - 76 cases $(61.3 \%)$. The profile of surgeons trained in this beginning of the new program was crucial for such a discrepancy as to other procedures. Besides that, even those surgeons who perform other types of operations chose gastroplasty, due to its good volume and standardization, two essential features in this initial training curve. This learning curve can be decreased according to several factors ${ }^{13}$. However, the volume of procedures is the main factor determining the learning curve, and this is clear for the training of the 10 (50\%) surgeons with higher volume, who reached the " 9 in 90" target. We should emphasize that we always encourage new training surgeons to choose operations they perform routinely, regardless of complexity. Nevertheless, Formisano et al. report that having or not experience in certain procedures by the conventional or laparoscopic methods may not be necessary ${ }^{14}$.

We regarded the operations by this new group as if this were again the atarting point of a robotic surgery program. As well as in the inception of our program years ago, we had no accidents or complications with the robotic platform, which is in agreement with other studies published in the literature that describe this beginning ${ }^{15-17}$. The cause of death of the patient submitted to pancreaticoduodenectomy had no relation with problems or errors due to the robotic platform. On the 16th postoperative day, the patient had an extensive intra-abdominal bleeding after the apparent resolution of a biliary fistula that lasted for 10 days. The patient was in the ward with scheduled discharge and ended up being subjected to an emergency laparotomy that showed a lesion of the dorsal pancreatic artery, probably caused by the corrosion of the vessel by the biliary secretion.

As a major limitation of the study, we acknowledge the lack of statistical calculation of the sample, so that these results could be representative of the population of surgeons who perform this training. As the study was descriptive, we used a convenience, non-probabilistic, non-random sample. The main idea was to describe the initial experience of the first year of training in robotic surgery using the model created by the Brazilian College of Surgeons.

\section{CONCLUSION}

Our initial sample of surgeons submitted to the new training model proposed by the $C B C$ had good acceptance and safety in the first training year. 


\title{
R E S U M O
}

\begin{abstract}
Objetivo: apresentamos nesse artigo o resultado da experiência inicial do nosso programa durante o treinamento dos primeiros cirurgiões no novo modelo de treinamento em cirurgia robótica proposto pelo CBC. Métodos: avaliamos retrospectivamente por coleta de dados e informações sobre treinamento no sistema robótico Da Vinci SI. As variáveis analisadas foram: Fase Pré-clínica: tempo de conclusão de cada uma das etapas por cirurgião, número de horas no simulador; Fase clínica: operações realizadas pelo grupo em treinamento, número de cirurgiões que realizaram nove procedimentos em noventa dias ("9 em 90"), tempo de docking, tempo de console, resultados cirúrgicos. Resultados: trinta e nove cirurgiões foram entrevistados para início do treinamento, 20 (51,3\%) chegaram à fase clínica. A média de idade dos cirurgiões foi de 47,9 (38 a 62) anos. O tempo médio entre a primeira entrevista e a entrega do certificado online foi de 64 dias (15 a 133). Os cirurgiões fizeram média de 51 h e 36 minutos de simulação robótica (40 a 83 minutos). O número total de casos em que os cirurgiões em treinamento participaram do ato cirúrgico como primeiro assistente foi de 418 casos, com média de 20,9 por cirurgião. O tempo de treinamento pré-clínico teve média de 116 dias (48 a 205 dias). Conclusão: o novo modelo proposto teve boa aceitação por todos os cirurgiões treinados e se mostrou seguro na amostra inicial.
\end{abstract}

Palavras chave: Telecirurgia Robótica. Treinamento. Procedimento Cirúrgico Robótico.

\section{REFERENCES}

1. Kwoh YS, Hou J, Jonckheere EA, Hayati S. A robot with improved absolute positioning accuracy for CT guided stereotactic brain surgery. IEEE Trans Biomed Eng. 1988;35(2):153-60.

2. Morrell ALG, Morrell-Junior AC, Morrell AG, Mendes JMF, Tustumi F, De-Oliveira-e-Silva LG, et al. The history of robotic surgery and its evolution: when illusion becomes reality. Rev Col Bras Cir. 2021;48:e20202798. doi: 10.1590/0100-6991e20202798. PMID: 33470371.

3. Jara RD, Guerrón $A D$, Portenier D. Complications of Robotic Surgery. Surg Clin North Am. 2020;100(2):461-8. doi: 10.1016/j. suc.2019.12.008. Epub 2020 Feb 13. PMID: 32169190.

4. da Vinci Surgery Community [Internet]. Join the Community to Access Training Materials. Available from: https://www.davincisurgerycommunity.com/ Training?tab1 $=$ TR

5. Nacul MP, Melani AGF, Zilberstein B, Benevenuto DS, Cavazzola LT, Araujo RLC, et al. Educational note: teaching and training in robotic surgery. An opinion of the Minimally Invasive and Robotic Surgery Committee of the Brazilian College of Surgeons. Rev Col Bras Cir. 2020;47:e20202681. doi: 10.1590/0100-6991e-20202681. Epub 2020 Aug 12. PMID: 32844912.

6. Azadi S, Green I, Arnold A, Truong M, Potts J, Martino MA. Robotic surgery: the impact of simulation and other innovative platforms on performance and training. J Minim Invasive Gynecol. 2021;28(3):490-
495. doi: 10.1016/j.jmig.2020.12.001. Epub 2020 Dec 10. PMID: 33310145.

7. Maerz DA, Beck LN, Sim AJ, Gainsburg DM. Complications of robotic-assisted laparoscopic surgery distant from the surgical site. $\mathrm{Br} J$ Anaesth. 2017;118(4):492-503. doi: 10.1093/bja/aex003.

8. Araujo RLC, Benevenuto DS, Zilberstein B, Sallum RA, Aguiar-Jr S, Cavazzola LT, et al. Overview and perspectives about the robotic surgical certification process in Brazil: the new statement and a national web-survey. Rev Col Bras Cir. 2020;47:e20202714. doi: 10.1590/0100-6991e-20202714.

9. Crewther BT, Shetty K, Jarchi D, Selvadurai S, Cook CJ, Leff DR, et al. Skill acquisition and stress adaptations following laparoscopic surgery training and detraining in novice surgeons. Surg Endosc. 2016;30(7):2961-8. doi: 10.1007/s00464-0154584-0. Epub 2015 Oct 20.

10. Bresler L, Perez M, Hubert J, Henry JP, Perrenot C. Residency training in robotic surgery: The role of simulation. J Visc Surg. 2020;157(3 Suppl 2):S123-S129. doi: 10.1016/j. jviscsurg.2020.03.006. Epub 2020 Apr 13.

11. Patel HRH. Simulation training in laparoscopy and robotic surgery. J Vis Surg. 2017;3:177. doi: 10.21037/jovs.2017.11.06.

12. Zhao B, Hollandsworth HM, Lee AM, Lam J, Lopez $N E$, Abbadessa $B$, et al. Making the Jump: $A$ Qualitative Analysis on the Transition From Bedside Assistant to Console Surgeon in Robotic Surgery Training. J Surg Educ. 2020;77(2):461-71. doi: 10.1016/j.jsurg.2019.09.015. Epub 2019 Sep 23. PMID: 31558428; PMCID: PMC7036000. 
13. Pernar LIM, Robertson FC, Tavakkoli A, Sheu EG, Brooks DC, Smink DS. An appraisal of the learning curve in robotic general surgery. Surg Endosc. 2017;31(11):4583-96. doi: 10.1007/s00464-0175520-2. Epub 2017 Apr 14.

14. Formisano G, Esposito S, Coratti F, Giuliani G, Salaj A, Bianchi PP. Structured training program in colorectal surgery: the robotic surgeon as a new paradigm. Minerva Chir. 2019;74(2):170-5. doi: 10.23736/S0026-4733.18.07951-8. Epub 2018 Nov 21.

15. Gest R, Nyangoh Timoh K, Chmielewski MC, Sardain H, Foucher F, Coiffic J, et al. [Robotic surgery program in gynecology: Lessons from the first 100 procedures]. Gynecol Obstet Fertil Senol. 2019;47(12):825-30. French. doi: 10.1016/j. gofs.2019.09.016. PMID: 31593818.

16. Pereira-Arias JG, Gamarra-Quintanilla M, SánchezVázquez A, Mora-Christian JA, Urdaneta-Salegui LF, Astobieta-Odriozola A, et al. How to build a robotic program. Arch Esp Urol. 2019;72(3):22738. English. PMID: 30945649.

17. Cerfolio RJ, Bryant AS, Minnich DJ. Starting a robotic program in general thoracic surgery: why, how, and lessons learned. Ann Thorac Surg. 2011;91(6):1729-36; discussion 1736-7. doi: 10.1016/j.athoracsur.2011.01.104. Epub 2011 May 6. PMID: 21529768.
Received in: 01/02/2021

Accepted for publication: 12/03/2021

Conflict of interest: no.

Funding source: none.

\section{Mailing address:}

Fernando de Barros

E-mail: barroscirurgia@gmail.com

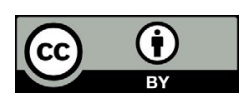

